\title{
Identification Of Cu Resistant Bacteria From Tin Mining-Affected Sea Sediment
}

\author{
Identifikasi Bakteri Resisten Cu Dari Sedimen Laut Terdampak Aktivitas Tambang \\ Timah
}

\author{
Rahmad Lingga $^{1^{*}}$, Budi Afriyansyah $^{1}$ \\ ${ }^{1}$ Jurusan Biologi Universitas Bangka Belitung Jl. Kampus Terpadu UBB, Balunijuk, \\ Kec. Merawang, Kota Bangka, Provinsi Kepulauan Bangka Belitung 33172 \\ *Email: linkgarahmad@gmail.com
}

Diterima 16 April 2020 dan Disetujui 17 Mei 2020

\begin{abstract}
Abstrak
Aktivitas pertambangan timah di laut memberikan pengaruh buruk terhadap kondisi lingkungan salah satunya adalah cemaran logam berat yang dapat mempengaruhi kehidupan biota perairan. Penelitian ini dilakukan untuk mengisolasi dan menguji resistensi bakteri sedimen laut terdampak aktivitas tambang timah terhadap logam berat $\mathrm{Cu}$. Pengambilan sampel dilakukan pada area penambangan timah di laut sampai ke hamparan lumpur kawasan mangrove terdekat. Isolasi bakteri dilakukan dengan metode cawan sebar dan karakterisasi bakteri meliputi pengamatan bentuk sel, pewarnaan Gram dan uji biokimia. Isolat bakteri selanjutnya diuji resistensinya terhadap logam $\mathrm{Cu}$ dengan konsentrasi $10 \mathrm{ppm}, 20 \mathrm{ppm}, 40 \mathrm{ppm}, 80 \mathrm{ppm}$ dan $100 \mathrm{ppm}$. Hasil penelitian memperlihatkan bahwa isolat bakteri yang berasal dari sedimen laut terdampak aktivitas tambang timah memiliki resistensi terhadap perlakuan logam berat $\mathrm{Cu}$ pada berbagai konsentrasi. Isolat B6, B8 dan A10 memperlihatkan resistensi tertinggi terhadap Cu sampai pada konsentrasi 100 ppm.

Kata kunci: bakteri resisten, logam berat $\mathrm{Cu}$, tambang timah, Bangka Belitung, sedimen laut

Abstract

Tin mining activity at sea has various negative influences on the environment. One of them is heavy metal contamination that can affect the life of fisheries biota. This research was conducted to isolate and test the $\mathrm{Cu}$ heavy metal resistance of marine sediment bacteria that are affected by tin mining activity. Sediment sampling was carried out in the area of tin mining to the mudflat neared to the mangrove area. Bacterial isolation was carried out by spread plate method and bacterial characterization included cell shape, Gram staining and biochemical tests. Furthermore, bacterial isolates were tested for resistance to metals with concentrations of $10 \mathrm{ppm}, 20 \mathrm{ppm}, 40 \mathrm{ppm}, 80 \mathrm{ppm}$ and $100 \mathrm{ppm}$. The results showed that bacterial isolates originating from marine sediments affected by mining activity were resistant to $C u$ heavy metal at various concentrations. Isolates B6, B8 and A10 showed the highest resistance up to the concentration of $100 \mathrm{ppm}$.

Keywords: resistant bacteria, heavy metal, tin mining, Bangka Belitung, marine sediment
\end{abstract}

\section{PENDAHULUAN}

Provinsi kepulauan Bangka Belitung merupakan daerah yang memiliki kekayaan mineral terutama timah yang sangat besar. Keberadaan cadangan timah yang sangat besar tersebut telah menjadikannya sebagai sumber penghasilan utama bagi pemerintah dan masyarakat Provinsi kepulauan Bangka Belitung. Misalnya pada tahun 2017, PT Timah dapat 
memproduksi 31.317 ton bijih timah dengan pendapatan usaha sebesar Rp. 9,217 triliyun dan jumlah laba yang diperoleh sebesar Rp. 502,4 miliyar (PT Timah 2017). Aktivitas penambangan timah sendiri telah berlangsung hampir 300 tahun lamanya, dengan penambangan timah di laut baru berlangsung kurang lebih 30 tahun. Pencabutan status timah sebagai komoditas strategis telah mendorong maraknya penambangan timah secara inkonvensional di laut. Penambangan timah di laut dilakukan oleh PT. Timah maupun pihak swasta sebagai mitra. Kegiatan penambangan timah di laut dilakukan dengan menggunakan kapal hisap. Sebagai contoh, Kapal Isap Produksi PT. Timah dapat menggali sampai kedalaman 25 meter di bawah permukaan laut (www.timah.com). Aktivitas penambangan timah di laut juga melibatkan penambangan inkonvensional yang dikenal dengan TI apung yang biasanya dilakukan oleh masyarakat maupun pengusaha swasta.

Di samping manfaatnya secara ekonomi, aktivitas penambangan timah dapat memberikan dampak negatif bagi lingkungan maupun kependudukan. Marfirani dan Adiatma (2012) mencermati tentang pengaruh penambangan timah di laut terhadap kualitas ekologis dan pendapatan penduduk yang bergantung perikanan laut. Hasil penelitian mereka mengungkapkan bahwa seringkali keberlanjutan lingkungan diabaikan demi kepentingan ekonomi. Pertambangan timah apung yang dilakukan masyarakat telah berdampak buruk bagi keberlanjutan ekologi. Pertambangan ini merupakan bagian dari trade off antara ekonomi dan lingkungan yang menyingkirkan peran lingkungan demi bertahan hidup.

Aktivitas pertambangan apung atau tambang inkonvensional (TI) apung menyebabkan peningkatan kerusakan lingkungan pesisir karena pengambilan pasir timah menjadi sulit dikendalikan. Limbah penambangan yang berupa tanah dan lumpur langsung dibuang ke laut. Akibatnya, kawasan perairan yang menjadi kawasan penambangan umumnya terlihat berwarna lebih gelap. Sedimentasi tanah menutup dan mematikan terumbu karang, dan sebaliknya alga merajalela yang menyebabkan kerusakan ekosistem pesisir. Kerusakan ini membawa dampak yang sangat negatif bagi lingkungan perairan. Seperti yang diketahui, terumbu karang merupakan tempat pemijahan ikan, penyeimbang ekosistem di lautan. (Marfirani dan Adiatma 2012). Di antara berbagai efek negatif yang mungkin terjadi sebagai efek samping pertambangan adalah keberadaan logam berat. Keberadaan logam berat pada konsentrasi tinggi menyebabkan efek negatif pada semua bentuk kehidupan (Martinez 2009).

Permasalahan lain yang perlu mendapatkan perhatian adalah potensi pencemaran logam berat sebagai buangan dari proses penambangan dan pengolahan timah. Penelitian ini bertujuan untuk mengisolasi bakteri dari sedimen laut yang terdampak aktivitas tambang timah inkonvensional dan menguji resistensinya terhadap logam berat $\mathrm{Cu}$.

\section{METODE}

\section{Lokasi dan teknik pengambilan sampel}

Penelitian ini dilakukan pada bulan Juni sampai dengan Desember 2019. Penelitian dilakukan di kawasan sekitar Pantai Sampur Desa Kebintik, Kecamatan Koba, Kabupaten Bangka Tengah, Provinsi Kepulauan Bangka Belitung. Lokasi penelitian terletak pada posisi $2^{\circ} 09^{\prime} 10.95^{\prime \prime} L S$ dan $106^{\circ} 10^{\prime} 49.47^{\prime \prime}$ BT. Pemilihan lokasi dilakukan dengan mempertimbangkan keberadaan pertambangan timah di laut di sekitar daerah tersebut. Jumlah stasiun yang diambil adalah empat stasiun yaitu tepi pantai, tengah, lokasi tambang, dan lumpur mangrove.

Sampel sedimen diambil dengan menggunakan sediment core sampai kedalaman $10 \mathrm{~cm}$ (sediment core dibuat dengan menggunakan pipa paralon PVC dengan diameter $4,8 \mathrm{~cm}$ ). Karakteristik fisik-kimia lokasi pengambilan sampel diukur langsung pada saat yang sama. Sampel kemudian dimasukkan ke dalam plastik steril dan disimpan dalam cool box untuk dibawa ke laboratorium.

\section{Isolasi dan Identifikasi Bakteri}


Sebanyak 20 sampel sedimen yang diambil kemudian dibawa ke laboratorium dengan menggunakan cool box untuk prosedur selanjutnya. Di laboratorium, prosedur pertama yang dilakukan adalah homogenisasi sampel yang dilakukan selama 1 menit. Setelah homogenisasi, sebanyak 1 gram sampel sedimen ditambahkan ke dalam $100 \mathrm{~mL}$ akuades. Cairan sampel kemudian diencerkan secara bertingkat sampai pengenceran $10^{-7}$. Sampel kemudian divorteks sebelum disimpan selama 24 jam pada suhu ruang. Sebanyak $100 \mu 1$ sampel kemudian disebar pada Media Zobell Agar. Selanjutnya, dilakukan perhitungan jumlah koloni dan pengamatan ciri-ciri koloni yang mewakili karakter tertentu seperti bentuk, tepi, warna, tekstur dan elevasinya. Koloni terpilih kemudian disubkultur dan dimurnikan sesuai dengan karakteristik masing-masing. Karakterisasi dan identifikasi yang dilakukan meliputi pengamatan bentuk sel, pewarnaan Gram dan uji biokimia yang meliputi uji Metil Red (MR), Voger Proskauer (VP), Sitrat, Indol.

\section{Uji Resistensi terhadap Logam Berat Cu}

Stok larutan (1M) logam berat (copper sulphate) disiapkan air deionisasi dan disterilkan dengan diautoklaf pada suhu $121^{\circ} \mathrm{C}$ selama 15 menit. Konsentrasi logam berat $\mathrm{Cu}$ yang digunakan sebanyak 5 variasi konsentrasi yaitu 10 ppm, 20 ppm, 40 ppm, 80 ppm dan 100 $\mathrm{ppm}$. Media tumbuh yang telah disuplementasi dengan logam berat $\mathrm{Cu}$, dituang ke dalam cawan Petri dan didinginkan. Selanjutnya, dilakukan inokulasi bakteri dengan metode cawan gores. Masing-masing perlakuan dibuat sebanyak 3 ulangan. Cawan disimpan dalam inkubator dengan posisi terbalik selama $2 \times 24$ jam. Pengamatan dilakukan pada biakan yang disimpan suhu $30^{\circ} \mathrm{C}$.

\section{Analisis Data}

Analisis data dilakukan secara deskriptif dengan menampilkan data dalam bentuk tabel dan grafik. Karakteristik sel bakteri ditampilkan dalam bentuk gambar.

\section{HASIL DAN PEMBAHASAN \\ Isolat Bakteri Sedimen Laut}

Jumlah total isolat bakteri sedimen laut yang diperoleh dari beberapa titik di kawasan Pantai Sampur adalah sebanyak 25 isolat, yang memperlihatkan keragaman dari segi morfologi sel dan ciri biokimianya (Tabel 1). Secara biokimia (uji MR, VP, sitrat dan indol), sebagian besar isolat menunjukkan karakteristik yang sama yaitu MR negatif, VP negatif, MR negatif, VP negatif. Ciri yang berbeda ditemukan pada 3 isolat lainnya yaitu isolat A2, A8 dan B15. Isolat A2 dan A8 memperlihatkan ciri MR positif, VP negatif, sitrat negatif dan indol negatif. Sementara itu isolat B8 memperlihatkan ciri MR negatif, VP negatif, MR positif, VP positif. Keragaman ciri sel dan uji biokimia tersebut memperlihatkan bahwa jenis bakteri yang berhasil dikarakterisasi memiliki kemungkinan yang beragam, baik secara taksonomis maupun secara ekologi. Ciri biokimia bakteri yang berbeda menjadi indikasi perbedaan cara hidup bakteri tersebut, seperti kemampuan dalam memanfaatkan sumber karbon yang tersedia. Hal ini sejalan dengan keberadaan bakteri yang dikenal memiliki peranan penting dalam siklus biogeokimia di lingkungan perairan (Santos et al 2011).

Tabel 1. Karakteristik Isolat Bakteri Sedimen Dari Pantai Sampur Bangka Selatan

\begin{tabular}{cccccclc}
\hline No & Isolat & MR & VP & Sitrat & Indol & Gram & Penampakan Sel \\
\hline 1 & A1 & - & - & - & - & Negatif & Diplococcus \\
2 & A2 & + & - & - & - & Negatif & Coccus, berantai \\
3 & A3 & - & - & - & - & Positif & Coccus, tunggal \\
4 & A4 & - & - & - & - & Positif & Basil, tunggal
\end{tabular}




\begin{tabular}{|c|c|c|c|c|c|c|c|}
\hline 5 & A6 & - & - & - & - & Negatif & Batang pendek, tunggal \\
\hline 6 & A7 & - & - & - & - & Positif & Dipobasil \\
\hline 7 & A8 & + & - & - & - & Positif & Coccus, tunggal \\
\hline 8 & A9 & - & - & - & - & Negatif & Coccus, tunggal \\
\hline 9 & A10 & - & - & - & - & Negatif & Basil, tunggal \\
\hline 10 & A12 & - & - & - & - & Positif & Coccus, tunggal \\
\hline 11 & $\mathrm{~A} 13$ & - & - & - & - & Negatif & Basil, tunggal \\
\hline 12 & $\mathrm{~A} 15$ & - & - & - & - & Negatif & Batang pendek, tunggal \\
\hline 13 & A16 & - & - & - & - & Negatif & Basil, tunggal \\
\hline 14 & B1 & - & - & - & - & Negatif & Batang pendek, tunggal \\
\hline 15 & B2 & - & - & - & - & Negatif & Basil, tunggal \\
\hline 16 & B3 & - & - & - & - & Negatif & Basil, rantai \\
\hline 17 & B4 & - & - & - & - & Negatif & Basil, tunggal \\
\hline 18 & B5 & - & - & - & - & Negatif & Basil, tunggal \\
\hline 19 & B6 & - & - & - & - & Positif & Basil, tunggal \\
\hline 20 & B7 & - & - & - & - & Negatif & Basil, tunggal \\
\hline 21 & B8 & - & - & + & + & Negatif & Basil, tunggal \\
\hline 22 & B9 & - & - & - & - & Positif & Coccus, tunggal \\
\hline 23 & $\mathrm{~B} 10$ & - & - & - & - & Negatif & Batang pendek, tunggal \\
\hline 24 & B12 & - & - & - & - & Negatif & Basil, tunggal \\
\hline 25 & B15 & - & - & - & - & Negatif & Batang pendek, tunggal \\
\hline
\end{tabular}

Dari hasil pewarnaan gram diketahui sebanyak 7 isolat bakteri tergolong ke dalam bakteri Gram positif dan 18 isolat lainnya tergolong ke dalam bakteri Gram Negatif. Berdasarkan penampakan sel, sebanyak 11 isolat yang memiliki bentuk sel basil dan penataan tunggal, 5 isolat dengan bentuk kokus dengan penataan tunggal, 5 isolat dengan bentuk batang pendek dengan penataan tunggal, 1 isolat dengan bentuk diplokokus, 1 isolat kokus berantai, 1 isolat diplobasil, dan 1 isolat basil dengan penataan berantai (Gambar 1).
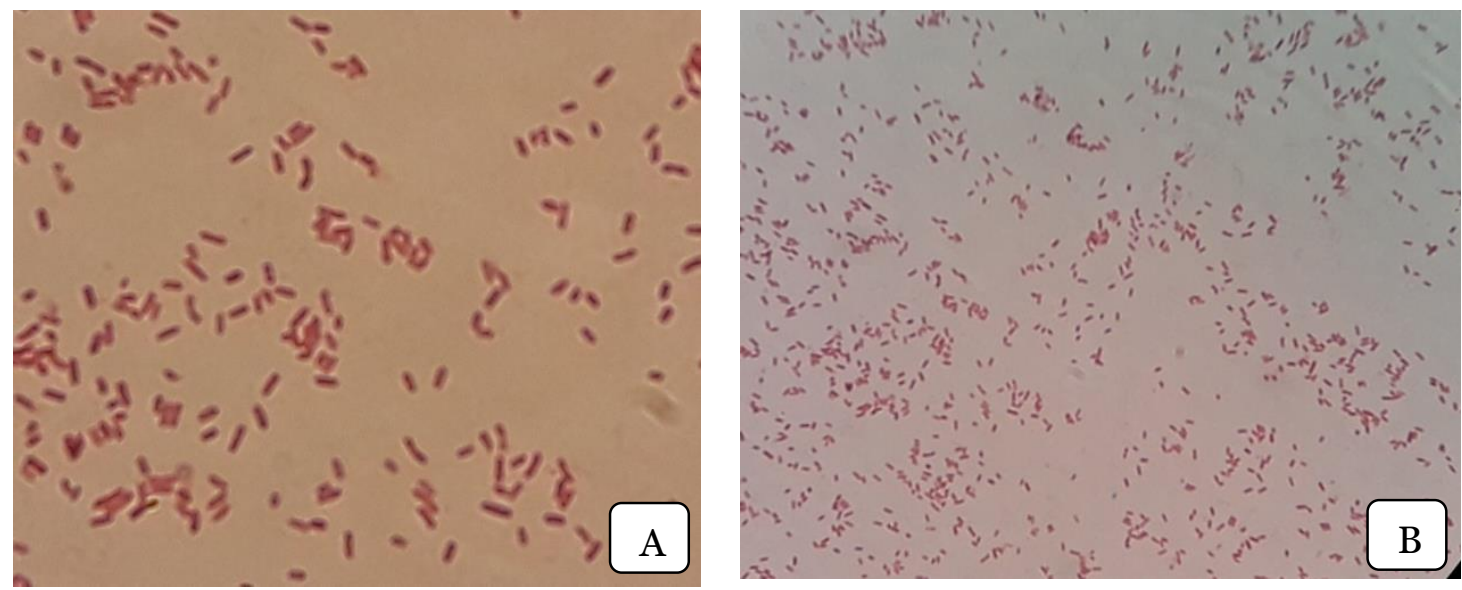


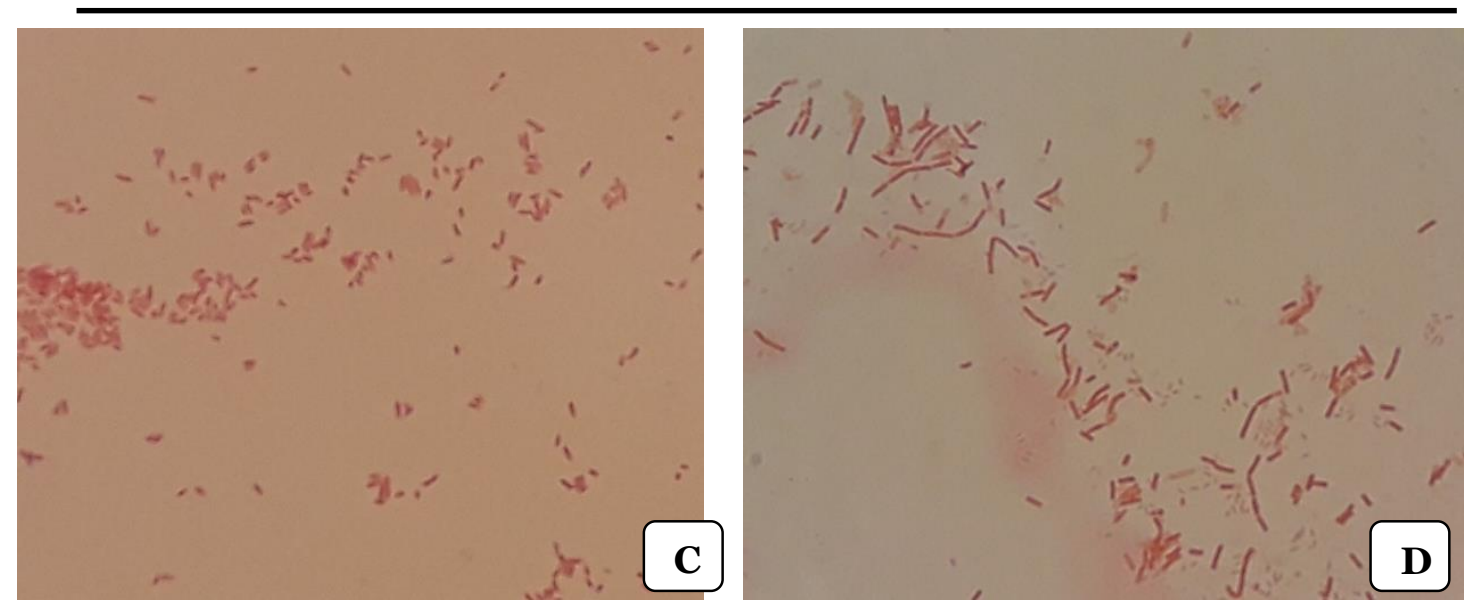

Gambar 1. Pewarnaan Gram dan bentuk mikroskopis sel isolat bakteri sedimen (A. Isolat A, B. Isolat B4, C. Isolat B10, D. Isolat B3)

\section{Resistensi terhadap logam berat $\mathrm{Cu}$}

Pengujian resistensi isolat bakteri dilakukan dengan menggunakan lima konsentrasi $\mathrm{Cu}$ berbeda yaitu 10 ppm, 20 ppm, 40 ppm, 80 ppm dan 100 ppm. Pemilihan konsentrasi ini didasarkan pada kenyataan bahwa belum ada studi pendahuluan tentang kadar logam berat $\mathrm{Cu}$ di lokasi tersebut sebelumnya, sehingga diambil pertimbangan bahwa ada kemungkinan bakteri di lokasi penelitian belum pernah atau telah terpapar logam berat $\mathrm{Cu}$ sebelumnya. Dari 25 isolat bakteri sedimen yang telah dimurnikan, dilakukan pengujian pada 10 isolat bakteri. Pemilihan isolat dilakukan berdasarkan pengelompokan Gram (Gram positif dan Gram negatif), bentuk dan penataan selnya.

Tabel 2. Resistensi isolat bakteri sedimen terhadap logam berat $\mathrm{Cu}$

\begin{tabular}{lcccccc}
\hline \multirow{2}{*}{ Isolat } & \multirow{2}{*}{ Kelompok Gram } & \multicolumn{6}{c}{ Konsentrasi (ppm) } \\
\cline { 2 - 7 } & Negatif & $\mathbf{1 0}$ & $\mathbf{2 0}$ & $\mathbf{4 0}$ & $\mathbf{8 0}$ & $\mathbf{1 0 0}$ \\
\hline A2 & Positif & ++ & ++ & + & + & + \\
A8 & Negatif & ++ & ++ & ++ & ++ & + \\
B3 & Negatif & ++ & ++ & + & + \\
B8 & Positif & ++ & ++ & ++ & ++ & ++ \\
A3 & Positif & ++ & ++ & + & + & + \\
A4 & Negatif & ++ & ++ & ++ & ++ & + \\
A9 & Negatif & ++ & ++ & ++ & ++ & ++ \\
A10 & Positif & ++ & ++ & ++ & ++ & ++ \\
B6 & Positif & ++ & ++ & ++ & + & + \\
B9 & & ++
\end{tabular}

Keterangan: $++=$ kepadatan populasi bakteri tinggi

$+\quad=$ kepadatan populasi bakteri rendah

Hasil pengujian memperlihatkan bahwa seluruh isolat bakteri yang diuji mampu tumbuh pada media yang telah disuplementasi dengan logam berat $\mathrm{Cu}$ (Tabel 2). Meskipun terlihat adanya perbedaan tingkat pertumbuhan bakteri berdasarkan ketebalan koloni yang tumbuh dalam media. Hal ini didefenisikan sebagai tingkat resistensi terhadap logam berat $\mathrm{Cu}$. Isolat bakteri yang memperlihatkan resistensi yang paling tinggi terhadap logam berat $\mathrm{Cu}$ adalah isolat B8, A10 dan B6. Masing-masing isolat terlihat dapat tumbuh dengan stabil pada semua konsentrasi logam berat $\mathrm{Cu}$ yang diujikan. Sementara itu, isolat bakteri yang memperlihatkan tingkat resistensi paling rendah terhadap logam berat $\mathrm{Cu}$ adalah isolat $\mathrm{A} 2$ dan A4. Kedua isolat tersebut terlihat mengalami penurunan kepadatan sel pada konsentrasi 40 ppm, $80 \mathrm{ppm}$ dan $100 \mathrm{ppm}$, sehingga terlihat adanya pola peningkatan resistensi bakteri 
terhadap konsentrasi logam berat $\mathrm{Cu}$ yang lebih tinggi. Hal ini memperlihatkan adanya perbedaan kemampuan bakteri tersebut dalam beradaptasi dengan kondisi lingkungan yang tercemar logam $\mathrm{Cu}$. Hal lain yang dapat mempengaruhi tingkat resistensi ini adalah kadar logam berat di habitat tersebut.

\section{Pembahasan}

Kemampuan bakteri untuk bertahan terhadap kondisi lingkungan yang terkontaminasi logam berat tergantung pada beberapa faktor antara lain karakteristik sel dan adaptasi mekanisme seluler yang dimilikinya. Shruti et al. (2012), menambahkan bahwa respon bakteri yang bervariasi terhadap logam berat berkaitan dengan perbedaan komposisi dinding sel dan mekanisme resistensi yang berlangsung dalam sel. Mekanisme adaptasi bakteri terhadap logam berat antara lain dengan mengeluarkan (eksklusi) ion logam berat dari dalam sel dengan merubah sistem transpor membran yang terlibat dalam akumulasi seluler awal. Bakteri juga dapat melakukan Sequestrasi intraseluler atau ekstraseluler kompponen pengikat logam yang mirip dengan metallothionein. Mekanisme lain yang dapat dilakukan antara lain sistem eflux kation/anion yang dikode oleh gen resistensi serta detoksifikasi logam berat secara enzimatik untuk mengurangi tingkat toksisitas logam berat (Hynninen et al 2009). Pada prokariot, misalnya bakteri Escherichia coli dikenal istilah Homeostasis Cu. (Dupont et al. 2014). Kelompok bakteri tersebut kemungkinan tidak memerlukan $\mathrm{Cu}$ sitoplasmik dan protein yang memerlukan $\mathrm{Cu}$ secara eksklusif terletak dalam periplasma atau dalam membran plasma (Rensing dan Grass 2003). Bakteri Gram Negatif diketahui memiliki sistem pertahanan terhadap kelebihan $\mathrm{Cu}$, bahkan juga dapat ditemukan pada kelompok Gram Positif (Dupont et al. 2014). Sementara itu, penelitian Lo Giudice et al. (2013) menemukan bahwa toleransi terhadap logam berat dari bakteri berkaitan dengan konsentrasi loam berat di lokasi tersebut. Hasil penelitian mereka di Terra Nova Bay memperlihatkan konsentrasi logam berat secara berurutan adalah $\mathrm{Cd}>\mathrm{Cu}>\mathrm{Zn}>\mathrm{Hg}$.

Bakteri yang memperlihatkan karakteristik yang resisten terhadap logam berat dan berasal dari daerah yang terpapar logam berat berpotensi untuk dijadikan agen bioremediasi cemaran logam berat (Chihomvu et al. 2014). Demikian halnya dengan temuan penelitian ini, resistensi bakteri asal sedimen laut yang terdampak aktivitas tambang dan terpapar logam berat, dapat menjadi dasar pemikiran tentang untuk dimanfaatkan menjadi agen bioremediasi cemaran logam berat di lingkungan perairan. Akan tetapi, dibalik peluang pemanfaatan bakteri resisten logam berat tersebut dalam remediasi lingkungan tercemar logam berat ada permasalahan lain yang perlu mendapatkan perhatian. Hal tersebut berkaitan dengan adanya korelasi positif antara resistensi bakteri terhadap logam berat dengan resistensi terhadap antibiotik tertentu. Hal ini terjadi melalui adanya respons adaptif komunitas bakteri terhadap kondisi lingkungan dan ada kemungkinan komunitas tersebut merupakan reservoir gen resistensi antibiotik (Beleneva et al. 2011). Resistensi antibiotik pada komunitas bakteri dapat dijadikan sebagai indikator pencemaran lingkungan (Zhang 2009).

Hal yang harus menjadi pertimbangan lain mengenai dampak pencemaran logam berat pada suatu ekosistem adalah adanya korelasi antara resistensi bakteri terhadap logam dengan biota lainnya. Jika bakteri mampu menoleransi keberadaan logam berat, dapat diduga bahwa hal tersebut menjadi indikator dari toksisitas potensial logam berat terhadap kelompok biota lainnya (Hassen et al. 1998). Perbedaan mekanisme resistensi bakteri terhadap logam berat dapat dijadikan sebagai dasar pertimbangan dalam pendekatan yang dilakukan dalam upaya bioremediasi (Filali et al. 2000; Malik 2004). Tomova et al. (2015) melaporkan bahwa beberapa genus bakteri yang potensial untuk diaplikasikan dalam upaya bioremediasi logam berat antara lain Pseudomonas, Janthinobacterium sp., Rhodococcus sp., Arthrobacter sp., Sporosarcina sp., Bacillus sp. Dan Burkholderia. 


\section{KESIMPULAN}

Isolat bakteri yang berasal dari sedimen laut terdampak aktivitas tambang timah memiliki resistensi terhadap perlakuan logam berat $\mathrm{Cu}$ pada berbagai konsentrasi. Resistensi bakteri sedimen terlihat lebih rendah pada konsentrasi yang lebih tinggi. Isolat B6, B8 dan A10 merupakan isolat yang memperlihatkan resistensi tertinggi terhadap $\mathrm{Cu}$ sampai pada konsentrasi $100 \mathrm{ppm}$.

\section{UCAPAN TERIMA KASIH}

Ucapan terimakasih disampaikan kepada LPPM Universitas Bangka Belitung yang telah mendanai penelitian ini.

\section{DAFTAR PUSTAKA}

Beleneva, IA,. Kukhlevskya, AD., Kharchenko UV., Kovalchuk, Y. 2011. Resistance to Copper Ions and Antibiotics in Marine Heterotrophic Bacteria in the Coastal Waters of Vietnam. Microbiol. 37(4): 284-290.

Chihomvu P., Stegmann P., Pillay M. 2014. Identification and Characterization of Heavy Metal Resistant Bacteria from the Klip River. Internatio J Biol Biomol Agri Food Biotechnol Enginee. 8(11): 1178-1188.

Dupont, CL., Grass G, Rensing C. 2014. Copper Toxicity and the Origin of Bacterial Resistance-New Insights and Applications. Metallomics. DOI: 10.1039/c1mt00107h.

Filali, BK, Taoufik J, Zeroual Y, Dzairi FZ, Talbi M, Blaghen M. 2000. Waste Water Bacterial Isolates Resistant To Heavy Metals and Antibiotics. Curr Microbiol. 41:151-156.

Hassen, A, Saidi N., Cherif M., Boudabous A. 1998. Resistance of Environmental Bacteria to Heavy Metal. Bioresour Technol. 64:7-15.

Hynninen, A., Touze T., Pitkanen L, Mengin-Lecreulx D, Virta M. 2009. An efflux transporter $\mathrm{PbrA}$ and a phospatase $\mathrm{PbrB}$ cooperate in a lead-resistance mechanism in bacteria. Mol. Microbiol. 74: 384-394.

Lo Giudice, A, Casella P, Bruni V, Michaud L. 2013. Response of bacterial isolates from Antarctic shallow sediments towards heavy metals, antibiotics and polychlorinated biphenyls. Ecotoxicology. 22:240-250.

Malik, A. 2004. Metal Bioremediation Through Growing Cells. Environ Int. 30:261-278.

Marfirani, R., Adiatma I. 2012. Pergeseran Mata Pencaharian Nelayan Tangkap Menjadi Nelayan Apung di Desa Batu Belubang. Prosiding Seminar Nasional Pengelolaan Sumberdaya Alam dan Lingkungan. Semarang, 11 September 2012.

Martinez, JL. 2009. Environmental Pollution by Antibiotics And by Antibiotic Resistance Determinants. Environ Pollut. 157: 2893-2902.

PT Timah Tbk. 2017. Laporan Tahunan. ID: Pangkal Pinang. 
Rensing, C., Grass G. 2003. Escherichia coli Mechanisms Of Copper Homeostasis In A Changing Environment, FEMS Microbiol. Rev. 27:197-213.

Santos, HF., Carmo FL, Paes JES, Rosado A, Peixoto RS. 2011. Bioremediation of Mangroves Impacted By Petroleum. Water, air, and Soil Pollution. 216: 329-350.

Tomova, I., Stoilova-Disheva M, Lazarkevich I., Vasileva-Tonkova E. 2015. Antimicrobial Activity And Resistance To Heavy Metals And Antibiotics Of Heterotrophic Bacteria Isolated From Sediment And Soil Samples Collected From Two Antarctic Islands. Frontiers in Life Science, 8(4): 348-357. DOI: 10.1080/21553769.2015.1044130.

Zhang, XX., Zhang T, Fang HHP. 2009. Antibiotic Resistance Genes In Water Environment. Appl Microbiol Biotechnol. 82: 397-414. 